\title{
INDUCING GENETIC VARIATION OF INNALA (SOLENOSTEMON ROTUNDIFOLIUS) VIA IN VITRO CALLUS CULTURE
}

\author{
D. P. PREMATILAKE \\ Horticulture Crop Research \& Development Institute, Department of Agriculture, Gannoruwa, Peradeniya.
}

(Accepted: 02 July 2004)

\begin{abstract}
Solenostemon rotundifolius (Poir.) J K Morton is an under-utilized tuber crop with very low genetic variability. Media protocols were developed to regenerate plants from leaf pieces (direct organogenesis) and stem-derived calli (indirect organogenesis) of $S$. rotundifolius in order to test the ability to generate variants. Differences with respect to plant structure, leaf colour and tuber size were observed in some of the regenerants. Variations occurred mainly when plants regenerated via indirect organogenesis. Novel banding patterns were observed with these plants in peroxidase analysis, confirming genetic variability. This is the first report on callus culture regeneration of $S$. rotundifolius.
\end{abstract}

Key words: peroxidase, plant regeneration, Solenostemon rotundifolius, variation

\section{INTRODUCTION}

Solenostemon rotundifolius Poir. $(2 \mathrm{n}=64)$ (Sinhala: Innala) known as country potato and Hausa potato, is an annual tuber crop belonging to family Lamiaceae (Mint family). It is grown mainly in countries of South-East Asia (Sri Lanka, Malaysia, Indonesia) and tropical Africa (Nigeria, Sudan). Tubers of this crop are consumed as a curry, baked or fried. Cooked tubers are granular in texture, white to cream in colour, moist and have an aromatic odour. When compared with other major tropical tuber crops such as cassava and sweet potato, innala has a relatively low starch content and hence the consumption of innala will contribute less to the fattening effect (Table 1).

Due to this reason, the demand for innala could be high in countries such as Europe and Middle East, where non-fattening foods are in high demand. Additionally, innala is a rich source of iron ${ }^{1 \& 2}$ than the other tuber crops (Table 1). Innala is generally free from pests and pathogens. However occasional attacks by leaf - eating caterpillars and a root nematode of Meloidegyne spp. have been observed. Innala, which is cultivated chiefly as a home garden crop, has emerged as a commercial crop with a market potential as an export crop, during the last decade.

The most unfavorable feature of innala is the small tuber size. On average, an innala tuber is about $2.5 \mathrm{~cm}$ in diameter. Round tubers with wider diameters are desirable not only with respect to high yield but also in the aspect of tuber cleaning and handling in culinary preparations.

Innala has an extremely low genetic variability. Sri Lanka has only two main identified varieties as 'Dik innala' and 'Bola innala'. The main difference between these varieties is in the tuber shape; elongated ('dik') and round ('bola') respectively. Important features such as number

Table 1: Composition of nutrients of some major edible tubers (per $100 \mathrm{~g}$ of edible tubers)

\begin{tabular}{lccccccc}
\hline Crop & $\begin{array}{c}\text { Starch } \\
(\mathrm{g})\end{array}$ & $\begin{array}{c}\text { Protein } \\
(\mathrm{g})\end{array}$ & $\begin{array}{c}\text { Fat } \\
(\mathrm{g})\end{array}$ & $\begin{array}{c}\text { Fibre } \\
(\mathrm{g})\end{array}$ & $\begin{array}{c}\text { Calcium } \\
(\mathrm{mg})\end{array}$ & $\begin{array}{c}\text { Iron } \\
(\mathrm{mg})\end{array}$ & $\begin{array}{c}\text { Phosphorus } \\
(\mathrm{mg})\end{array}$ \\
\hline Innala & $\mathbf{1 9 . 7}$ & $\mathbf{1 . 3}$ & $\mathbf{0 . 1 - 0 . 2}$ & $\mathbf{0 . 4 - 1 . 1}$ & $\mathbf{1 7}$ & $\mathbf{6 . 0}$ & - \\
Potato & 18.0 & 1.7 & $0.1-0.3$ & 0.6 & 13 & 1.1 & 51 \\
Cassava & 32.7 & 1.8 & $0.2-0.3$ & $1.1-1.3$ & 68 & 1.9 & 42 \\
Sweet potato & 24.3 & 1.2 & $0.2-0.5$ & $0.8-1.0$ & 33 & 2.0 & 38 \\
Colocasia & $13-29$ & $\mathbf{1 . 4 - 3 . 0}$ & $0.16-0.36$ & $0.6-1.18$ & - & - & - \\
Xanthosoma & $17-26$ & $1.3-3.7$ & $0.2-0.4$ & $0.6-1.92$ & - & - & - \\
\hline
\end{tabular}

Source: Tindall (1993); Gunasena (1994) 
of days to maturity, dry matter content (\%) and quality traits (i.e. taste of tuber flesh, texture, moistness etc.) are similar in these types. Recombinant breeding of this crop is hampered due to barriers in sexual crossing such as sporadic flowering and pollen sterility. Hence the only mode of inducing genetic variability of innala depends on vegetative mutation and not on recombinant breeding.

Somaclonal variation occurring in tissue culture has proven to be a potential means of crop improvement. Some varieties may exhibit characters superior to the original plant and may grow more vigorously than the source plant. It may be due to a random mutation at DNA level. Somaclonal variation of useful agronomic traits such as tuber shape, yield and maturity and disease resistance etc. has occurred in potato. ${ }^{3}$ Screening for superior somaclonal variants can help in obtaining improved crop cultivars.

Since innala is an easily cultivable tuber crop and could be used as a substitute for potato, it is worthwhile to extend tissue culture technology to this crop since there is no other successful option available for genetic improvement. In vitro technology has not been applied to this crop although lateral buds of innala have been used for cryopreservation. ${ }^{4}$ Callus culture and a plant regeneration system were therefore developed for innala and the ability of this system to generate variations was tested.

\section{METHODS \& MATERIALS}

Formation of in vitro axenic cultures of innala: Young shoots were collected from a healthy mother plant (cv. bola innala) maintained in the plant house. They were surface - sterilized, ${ }^{7}$ trimmed down to $0.5-1.0 \mathrm{~cm}$ pieces and cultured in hormone-free $\mathrm{MS}^{5}$ medium containing sucrose $3 \%(\mathrm{w} / \mathrm{v})$ and solidified with agar $(0.8 \%)$. When these shoots grew and formed plantlets, they were sub cultured at 3 wk intervals and used as source material to obtain leaves and stem pieces for the study as well as the control.

Shoot regeneration from leaf explants of innala: direct organogenesis: Immature leaf pieces $(0.5 \mathrm{X}$ $0.5 \mathrm{~cm}^{2}$ ) from in vitro grown axenic innala plants were cultured in a pre-specified medium consisting $\mathrm{MS}^{5}$ basal salts, organic compounds of $\mathrm{NN}^{6}$, sucrose $4 \%(\mathrm{w} / \mathrm{v})$, naphthalene acetic acid (NAA at $0.5 \mathrm{mg} / \mathrm{L}$ ) and benzyl amino purine (BAP at $5.0 \mathrm{mg} / \mathrm{L}$ ) to induce shoot regeneration. ${ }^{7}$ Cultures were incubated at $25 \pm 1^{\circ} \mathrm{C} / 10 \mu \mathrm{Es}^{-1} \mathrm{~m}^{-2} /$ $10 \mathrm{~h}$ for $3 \mathrm{wk}$. Regenerated shoots were separated and cultured in a plant growth medium to promote plantlet development.

Shoot regeneration from stem explants of innala via a callus phase: indirect organogenesis: Stem pieces were obtained from axenic innala plants and the immature portions (up to $2.5 \mathrm{~cm}$ from top) were thinly sliced ( $1 \mathrm{~mm}$ thickness). These stem explants were cultured on $\mathrm{MS}^{5}$ medium with sucrose $4 \%(\mathrm{w} / \mathrm{v}), \mathrm{NAA}(2.0 \mathrm{mg} / \mathrm{L})$ and $\mathrm{BAP}(0.8$ $\mathrm{mg} / \mathrm{L})$ in $9 \mathrm{~cm}$ Petri dishes and incubated under the same conditions as before. Callus formation occurred after $3-4 \mathrm{wk}$ and they were separated from the mother explants and sub cultured in freshly - prepared medium to propagate calli.

In order to obtain plants, the calli were then transferred to (a) $\mathrm{MSP}_{1}$ : $\mathrm{MS}^{5}$ medium with sucrose $3 \%(\mathrm{w} / \mathrm{v}), \mathrm{NAA}(2.0 \mathrm{mg} / \mathrm{L}) \mathrm{BAP}(0.5 \mathrm{mg} / \mathrm{L})$ and (b) $\mathrm{UM}^{8}$ medium with same growth regulators and sucrose as in $\mathrm{MSP}_{1}$ and incubated as before. After $2-3$ wk, the calli, which turned green were transferred to five MS (1962)-based media with sucrose $3 \%(\mathrm{w} / \mathrm{v})$ agar $(0.8 \% \mathrm{w} / \mathrm{v})$ and several combinations of NAA and BAP (Table 2) since previous studies showed this hormone combination was beneficial to innala (Prematilake, unpublished data). Cultures were incubated at $25 \pm 1^{\circ} \mathrm{C} / 37 \mu \mathrm{Em}^{-1} \mathrm{~s}^{-2} / 10 \mathrm{~h}$ for $4-5$ wk. When shoots appeared from the calli, they were separated and only the healthy shoots were cultured in a plant growth medium (MS medium, sucrose $3 \% \mathrm{w} / \mathrm{v}$, agar $0.8 \% \mathrm{w} / \mathrm{v}$ ) to promote rooting. The axenic plantlets were used as controls throughout the study.

Glasshouse establishment:All plants were acclimatized ${ }^{7}$ and planted in pots $(15 \mathrm{~cm})$ and kept in the glass house. Each plant was labelled individually. Leaf regenerants (08 plants) were coded as LR $(1-8)$ and stem calli - regenerants (23 plants) were coded as CR $(1-23)$. Five shoottip cultured plants were also pot planted to be used as the controls. All plants were raised under the same conditions and soil mixture and subjected to similar agronomic practices. At the 
end of 6 months, tubers were harvested and the number of tubers per plant, individual tuber weight $(\mathrm{g})$ and tuber diameter $(\mathrm{cm})$ were recorded. Tubers weighing less than $2.0 \mathrm{~g}$ were discarded since they were very small and only tubers heavier than $2.0 \mathrm{~g}$ were selected for data analysis.

Table 2: Composition of regeneration media

\begin{tabular}{lcc}
\hline \multirow{2}{*}{ Media name } & \multicolumn{2}{c}{$\begin{array}{c}\text { Hormone concentration } \\
(\mathrm{mg} / \mathrm{l})\end{array}$} \\
\cline { 2 - 3 } & $\mathrm{NAA}$ & BAP \\
\hline $\mathrm{MSP}_{1}$ & 2.0 & 0.5 \\
$\mathrm{MSP}_{2}$ & 1.0 & 0.5 \\
$\mathrm{MSP}_{3}$ & 2.0 & 1.0 \\
$\mathrm{MSP}_{4}$ & 0.5 & 2.0 \\
$\mathrm{MSP}_{5}$ & 0.1 & 1.0 \\
\hline
\end{tabular}

Statistical analysis: Data on tuber weight and tuber diameter were analyzed using ANOVA considering the regeneration methods as treatments with the aid of statistical software MINITAB.

\section{Detection of variability}

(a) Morphology: Glass house - grown plants were checked periodically to detect any differences in plant structure, leaf colour, leaf size and internodal distances.

(b) Isozyme analysis to detect variability: Isozymes are considered as a sensitive marker system for genetic and physiological changes preceding differentiation in cultured cells.

Immature leaves from glass house grown plants (regenerants and controls) were collected and labeled separately. From each plant, $1.5 \mathrm{~g}$ leaves were ground with $1.0 \mathrm{ml}$ extraction buffer (Appendix 1). The extract was centrifuged at $3500 \mathrm{rpm}$ for $5 \mathrm{~min}$ at room temperature with a small quantity $(0.2 \mathrm{~g})$ of Sephadex G 50 to obtain the soluble fraction of protein. The crude extract was loaded $(30 \mu \mathrm{l})$ into polyacrylamide gel and electrophorated using a constant electric current (20 $\mathrm{mA} \mathrm{DC}$ ) for $3 \mathrm{~h}$ until the tracking dye (Bromophenol blue) reached the end of the gel: The gels were then stained for $15-20 \mathrm{~min}$ for peroxidase isoenzyme (Appendix 11). Stained gels were washed with water fixed in $7 \%(\mathrm{v} / \mathrm{v})$ acetic acid solution and photographed. The relative migration or Rf values for bands were calculated and zymograms were constructed. 3 to 4 samples were prepared from each plant.

$\mathrm{Rf}=\frac{\text { Distance travelled by the isozyme band }}{\text { Migration distance of the marker dye front }}$

\section{RESULTS \& DISCUSSION}

\section{Plant regeneration from cultured tissues}

Multiple shoots appeared from the cut-surfaces of the leaf explants (Figure 1A). When transferred to plant growth medium, those shoots developed into healthy plantlets with a good root system.

Stem calli, which were pale yellow in colour initially, turned green upon subculture in the $\mathrm{MSP}_{1}$ regeneration medium. Calli in UM medium turned yellow colour which later turned into green. When sub cultured in $\mathrm{MSP}_{1} \rightarrow \mathrm{MSP}_{5}$ media, only the calli that were initially cultured in MSP1 produced green buds and subsequently shoots (Table 3). No shoot development occurred in calli that came from UM medium or in the MSP media with higher NAA. The result showed that UM medium is detrimental for regeneration. The media sequence therefore suitable for regeneration from innala calli were $\mathrm{MSP}_{1} \rightarrow \mathrm{MSP}_{4}$ and $\mathrm{MSP}_{1} \rightarrow \mathrm{MSP}_{5}$ which produced 4 and 2 shoots per calli respectively. However, since shoots produced in $\mathrm{MSP}_{5}$ had a good vigor, $\mathrm{MSP}_{1} \rightarrow \mathrm{MSP}_{5}$ media combination was selected for shoot regeneration from innala calli (Figure 1B). Shoots that developed from these green calli grew into plantlets in the plant growth medium and were transferred to the glass house.

\section{Detection of variability}

\section{Morphological differences}

Variations occurred in plant structure, where long and thin stems with smaller leaves (CR 21) and short, sturdy stems with thick leaves (CR 11) were observed (Figure 1C). Differences were also noted in leaf colour of some regenerants where plants with purple pigmentation either around leaf edges (CR 15) or on the whole leaf (LR 6) were observed. 


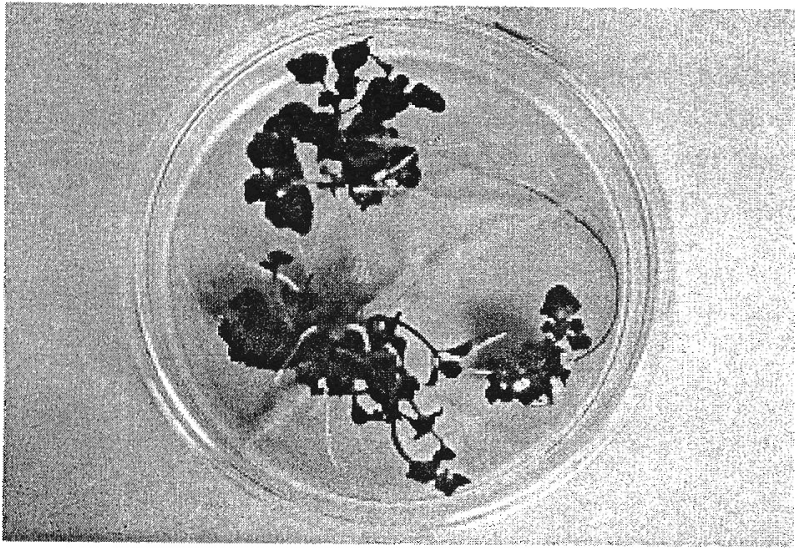

$1 \mathrm{~A}$

a

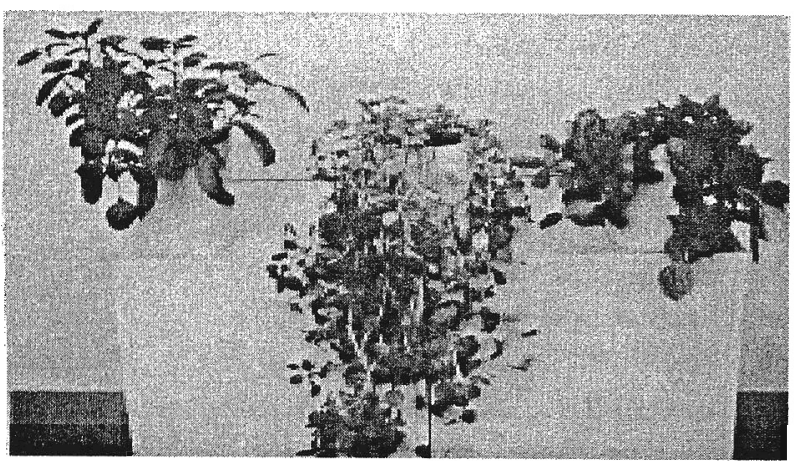

$1 \mathrm{C}$

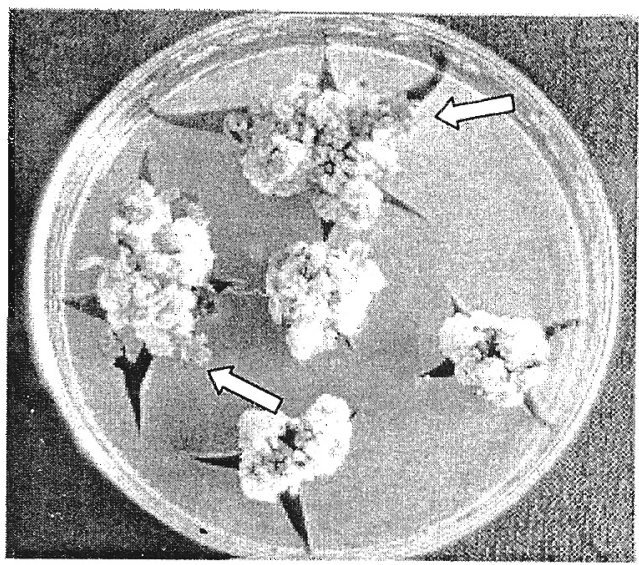

$1 \mathrm{~B}$

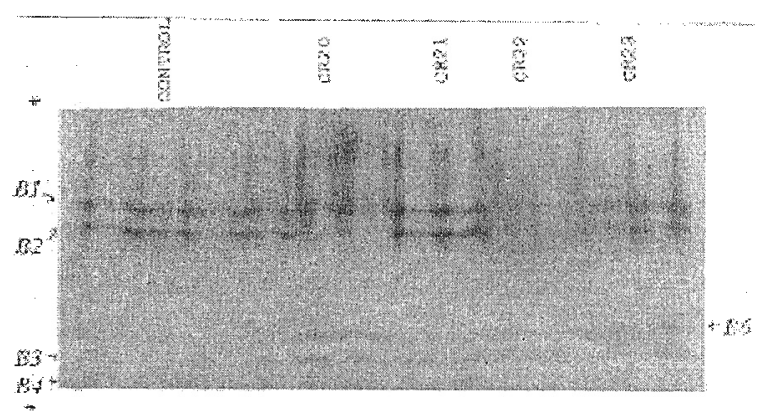

$1 \mathrm{D}$

Figure 1: In vitro plant regenexation of S. rotundifolius cv. bola innala

1A. Shoot regeneration from leaf tissues ( $x 0.6$ )

1B. Shoot regeneration from stem calli (arrows indicate regenerating shoots; $\mathrm{x} 0.7$ )

1C. Plant structure of regenerated plants (x 0.08)

a. Shoot - tip cultured plant (control)

b. CR21 with thin, long stems and small leaves

c. CR11 with short, sturdy stems and thick leaves

1D. Peroxidase analysis of tissue cultured innala plants

$\mathrm{B}_{1}-\mathrm{B}_{4}$. Bands corresponding to control plants

$B_{6}$. A novel band observed in some of the regenerated plants

\section{Tuber characteristics}

Tuber characters of glass house - grown tissue cultured innala plants are shown in Table 4. According to the results, the most marked feature in tuber characters was the wide variability in tuber weight. Tubers were in a cluster containing many tubers of different sizes. Statistical analysis of the data showed that both tuber weight and tuber diameter were significantly different among the three regeneration methods (Table 5) and the tubers of indirectly regenerated plants, i.e. calli regenerants, were generally larger than those from the other regeneration methods. This indicates a possibility of altering tuber size from these regeneration methods.

\section{Peroxidase analysis}

Novel isoenzyme banding patterns were observed in some of the regenerated plants (Figure 1D). Among leaf - regenerated plants, only 2 out of 8 plants showed different banding patterns (LR6 and LR7) (Fig. 2). The control had 04 bands at 0.43 (B1), 0.50 (B2), 0.86 (B3) and 0.90 (B4) positions. All leaf regenerants (LR) had $B 1$ and 
Table 3: Shoot regeneration response from stem calli of innala

\begin{tabular}{|c|c|c|c|c|c|}
\hline $\begin{array}{l}\text { Media } \\
\text { calli }\end{array}$ & $\begin{array}{c}\text { Calli } \\
\text { growth }\end{array}$ & $\begin{array}{c}\text { Calli } \\
\text { greening }\end{array}$ & \# Shoots / calli & Rooting & Necrosis \\
\hline $\mathrm{MSP}_{1} \rightarrow \mathrm{MSP}_{1}$ & +++ & ++ & 00 & - & + \\
\hline $\mathrm{MSP}_{1} \rightarrow \mathrm{MSP}_{2}$ & $++t$ & ++ & 00 & - & + \\
\hline $\mathrm{MSP}_{1} \rightarrow \mathrm{MSP}_{3}$ & ++ & ++ & 00 & - & + \\
\hline $\mathrm{MSP}_{1} \rightarrow \mathrm{MSP}_{4}$ & ++ & $+/++$ & $4 \pm 2$ & - & $-1+$ \\
\hline $\mathrm{MSP}_{1} \rightarrow \mathrm{MSP}_{5}$ & $-1+$ & $-1+$ & $2 \pm 1$ & - & $-1+$ \\
\hline $\mathrm{UM} \rightarrow \mathrm{MSP}_{1}$ & $++/+++$ & - & 00 & - & + \\
\hline $\mathrm{UM} \rightarrow \mathrm{MSP}_{2}$ & $++/+++$ & tt & 00 & - & $+/++$ \\
\hline $\mathrm{UM} \rightarrow \mathrm{MSP}_{3}$ & $++/++++$ & $+/++$ & 00 & - & $+1++$ \\
\hline $\mathrm{UM} \rightarrow \mathrm{MSP}_{4}$ & $++/+++$ & $-1++$ & s.i. $^{*}$ & - & $+/++$ \\
\hline $\mathrm{UM} \rightarrow \mathrm{MSP}_{5}$ & ++ & + & 00 & - & ++ \\
\hline
\end{tabular}

${ }^{*}$ : shoot initiation only

- : no response + : low $\quad++$ : medium $\quad+++$ : high $\quad++++$ : very high

$B 2$ bands but in LR $7, B 3$ and $B 4$ were absent. New bands appeared in LR 6 at 0.73 (B5) and 0.77 $B 6$ and in LR7, two new bands were present as $B 6$ and at 0.93 (B7) positions. In calli regenerated plants, 10 out of 23 plants (CR11, CR13, CR16 - CR23) exhibited different patterns as compared to controls (Fig.3). All these plants had $B 6$ band as a new band. The $B 4$ band was missing in CR13, CR18 and CR19 while $B 2$ band was missing in CR16 and CR17. Both $B 1$ and $B 2$ bands did not appear in CR20 and CR22 plants.

During regeneration, the differentiated plant cells become undifferentiated and then redifferentiated via a new pathway of development. Changes may happen during this process, with respect to chromosomal fragmentation, gene mutation, DNA amplification etc. $^{9}$ that cause changes in regenerated plants. Culture environment and growth regulators in the medium could also affect the cell cycle of in vitro plants, causing somaclonal variants. ${ }^{10}$

When morphological and tuber characters of the regenerated $S$. rotundifolius plants were compared with the results of peroxidase analysis, a clear - distinguishable correlation could not be detected. However, LR 6 plant, which had purple coloured leaves, had a new band, B5, which was not present in any other plant. Plants CR21 and CR11, which had modified plant morphology (thin, long stems with small leaves and short, sturdy stems with thick leaves respectively) exhibited $B 6$ band, but CR23, which had a similar banding pattern did not show this variation. On the other hand, no peroxidase variation could be detected in CR 15 which exhibited purple pigmentation around leaf edges. Plants with large - sized tubers (CR16) had the new B6 band but it could not be correlated with the tuber size since CR17 that had the same banding pattern did not have large tubers. It should be noted that these variations were observed with only peroxidase isoenzyme which has been used by several workers in cell / callus differentiation studies. ${ }^{11 \& 12}$ More and different patterns could be expected if other isozyme systems such as esterase and GOT (aspartate amino transferase) were also used. However, differences in banding patterns were more in stem calli - regenerants (43\%) than in leaf regenerants $(25 \%)$. 
Table 4: Tuber characteristics of tissue cultured innala

\begin{tabular}{|c|c|c|c|}
\hline Plant code & $\begin{array}{c}\text { Number of tubers } \\
(2.0<\mathrm{g})\end{array}$ & $\begin{array}{l}\text { Average tuber weighta } \\
(\mathrm{g})\end{array}$ & $\begin{array}{l}\text { Average tuber diameter } \\
(\mathrm{cm})^{b}\end{array}$ \\
\hline \multicolumn{4}{|c|}{ Direct regeneration } \\
\hline LR 1 & 10 & 7.6 & 3.1 \\
\hline LR 2 & 14 & 8.5 & 3.3 \\
\hline LR 3 & 14 & 8.9 & 3.0 \\
\hline LR 4 & 17 & 6.6 & 3.0 \\
\hline LR 5 & 26 & 5.5 & 3.1 \\
\hline LR 6 & 14 & 6.2 & 2.8 \\
\hline LR 7 & 15 & 7.3 & 3.4 \\
\hline LR 8 & 11 & 4.9 & 3.1 \\
\hline \multicolumn{4}{|c|}{ Indirect regeneration } \\
\hline CR 1 & 07 & 11.2 & 3.7 \\
\hline CR 2 & 08 & 11.5 & 3.5 \\
\hline CR 3 & 15 & 10.0 & 3.3 \\
\hline $\mathrm{CR}_{4}$ & 12 & 8.9 & 3.3 \\
\hline CR 5 & 12 & 11.0 & 3.5 \\
\hline CR 6 & 16 & 10.0 & 3.3 \\
\hline $\mathrm{CR} 7$ & 07 & 9.5 & 3.3 \\
\hline CR 8 & 17 & 7.3 & 3.7 \\
\hline CR 9 & 18 & 9.0 & 3.4 \\
\hline CR 10 & 04 & 4.3 & 2.6 \\
\hline CR 11 & 09 & 6.2 & 2.9 \\
\hline $\mathrm{CR} 12$ & 09 & 8.2 & 3.3 \\
\hline $\mathrm{CR} 13$ & 14 & 6.2 & 2.8 \\
\hline CR 14 & 14 & 7.1 & 3.0 \\
\hline CR 15 & 10 & 8.1 & 3.3 \\
\hline CR 16 & 06 & 23.7 & 4.4 \\
\hline CR 17 & 11 & 7.5 & 3.4 \\
\hline CR 18 & 12 & 9.3 & 3.4 \\
\hline CR 19 & 09 & 10.0 & 3.7 \\
\hline CR 20 & 05 & 10.0 & 3.4 \\
\hline CR 21 & 05 & 12.1 & 2.9 \\
\hline CR 22 & 15 & 3.1 & 3.0 \\
\hline CR 23 & 06 & 9.1 & 3.2 \\
\hline Control ${ }^{\mathrm{C}}$ & 09 & 9.4 & 3.4 \\
\hline
\end{tabular}

${ }^{\mathrm{a}}$ : Average tuber weight $=$ total tuber weight per plant / number of tubers per plant

b: Average tuber diameter = total tuber diameter of each plant / number of tubers per plant

c: Control values consists of an average of 05 plants

\section{CONCLUSION}

Results of this study show that plant regeneration system proposed here using indirect regeneration (i.e. via a callus phase) could induce more variants in $S$. rotundifolius plants as compard to direct regeneration. Once variations occur, it is possible to maintain such characters throughout generations by clonal propagation of this plant.
Since innala is a crop with barriers for sexual breeding, this technique has the potential to induce genetic variations that will be useful in improvement of this crop.

Furthermore, this study revealed that the present plant regeneration system has the ability to alter the tuber size of Solenostemon. Hence, further experimentation with this method can 
Table 5: Statistical comparison of regeneration method on weight and diameter of innala tubers

\begin{tabular}{lcc}
\hline Regeneration method & Mean tuber weight $(\mathrm{g})^{\mathrm{a}}$ & Mean tuber diameter $(\mathrm{cm})^{\mathrm{a}}$ \\
\hline Direct regeneration & $6.9 \pm 4.5$ & $3.0 \pm 0.7$ \\
Indirect regeneration & $9.0 \pm 7.2$ & $3.3 \pm 0.9$ \\
Control & $8.8 \pm 7.0$ & $3.2 \pm 1.1$ \\
LSD @ 5\% & 4.12 & 3.59 \\
\hline
\end{tabular}

a: Statistically significant at $5 \%$ probability

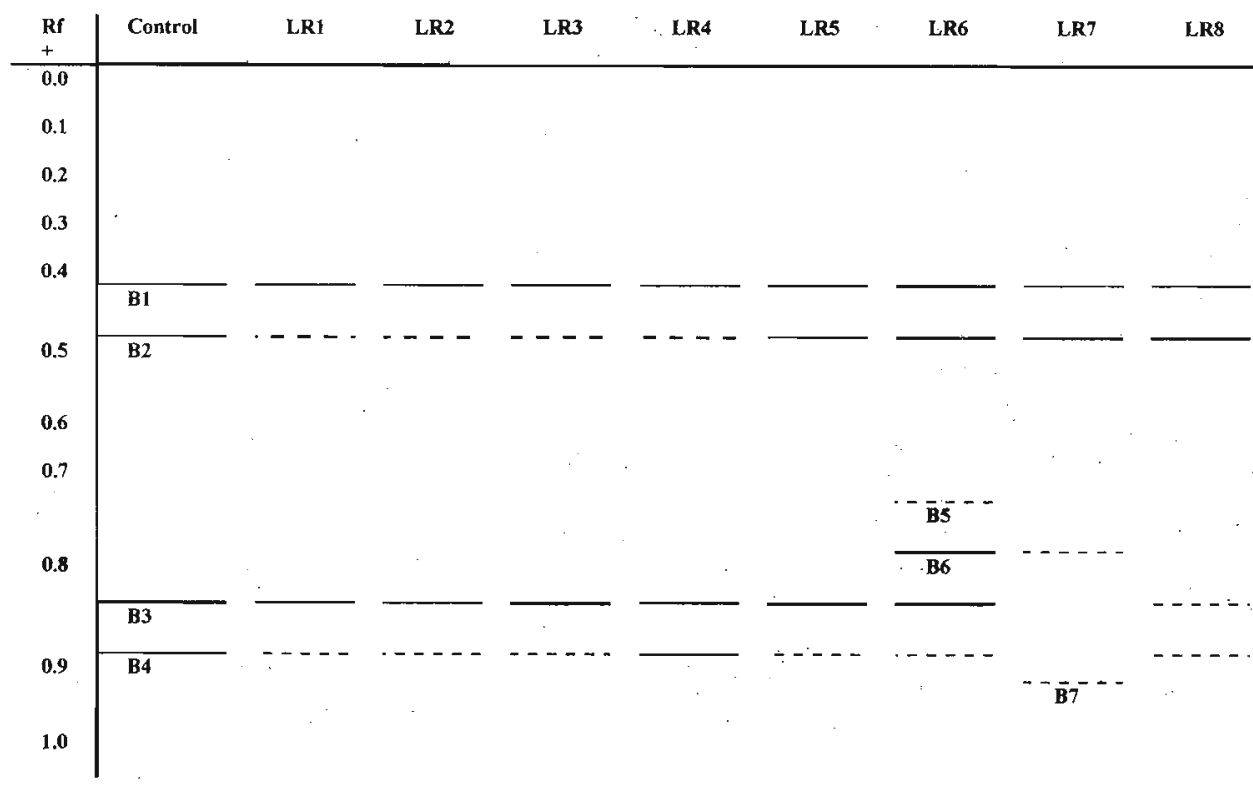

Figure 2: Zymogram of Peroxidase analyses for leaf-derived innala plants

Control : shoot-tip cultured plants

I,R 1 - LRS : Leif derived plants

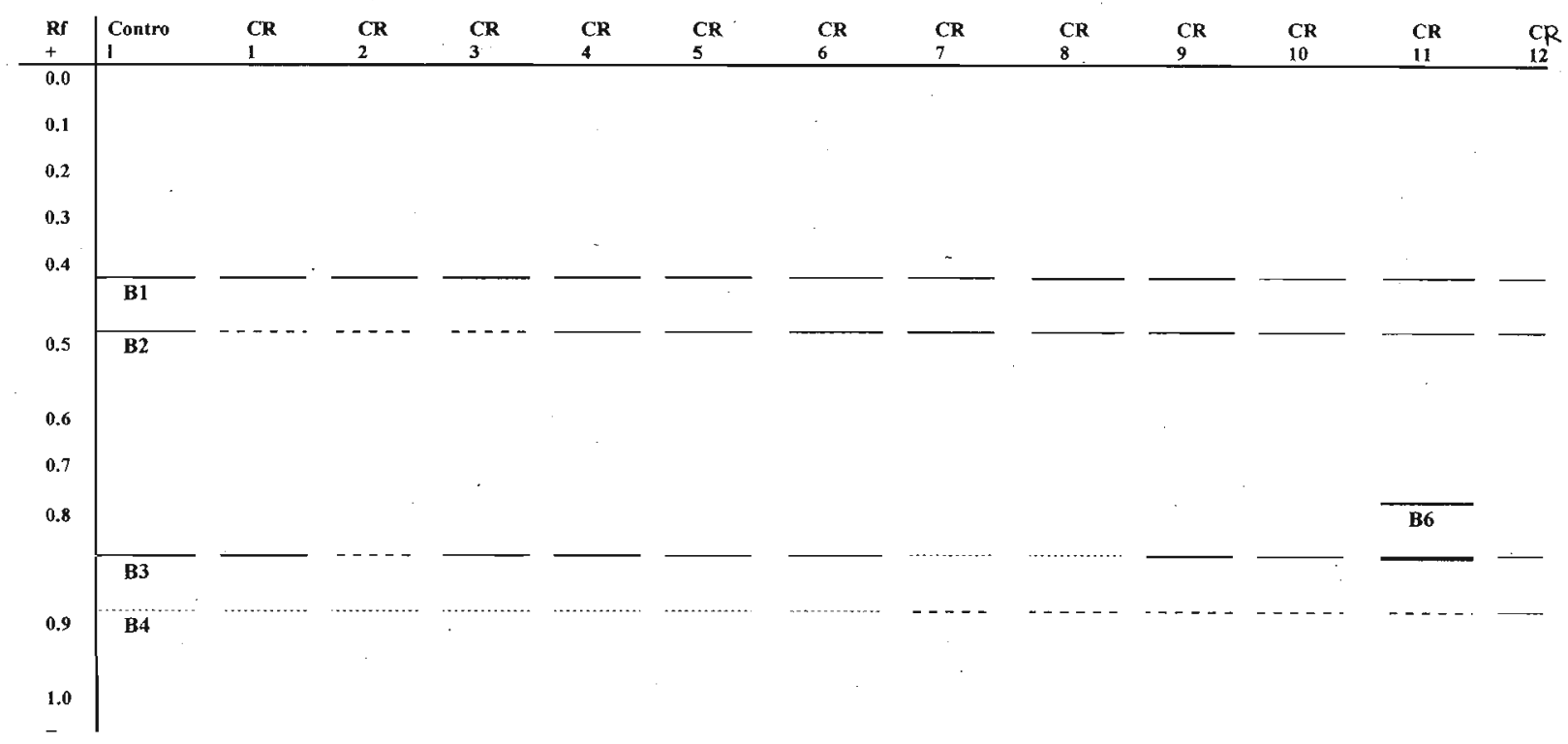

Figure 3: Zymogram of Peroxidase analysis for stem calli - derived innala plants

Control : Shoot-tip cultured plants

CR1 - CR12 : Stem calli - derived plants 


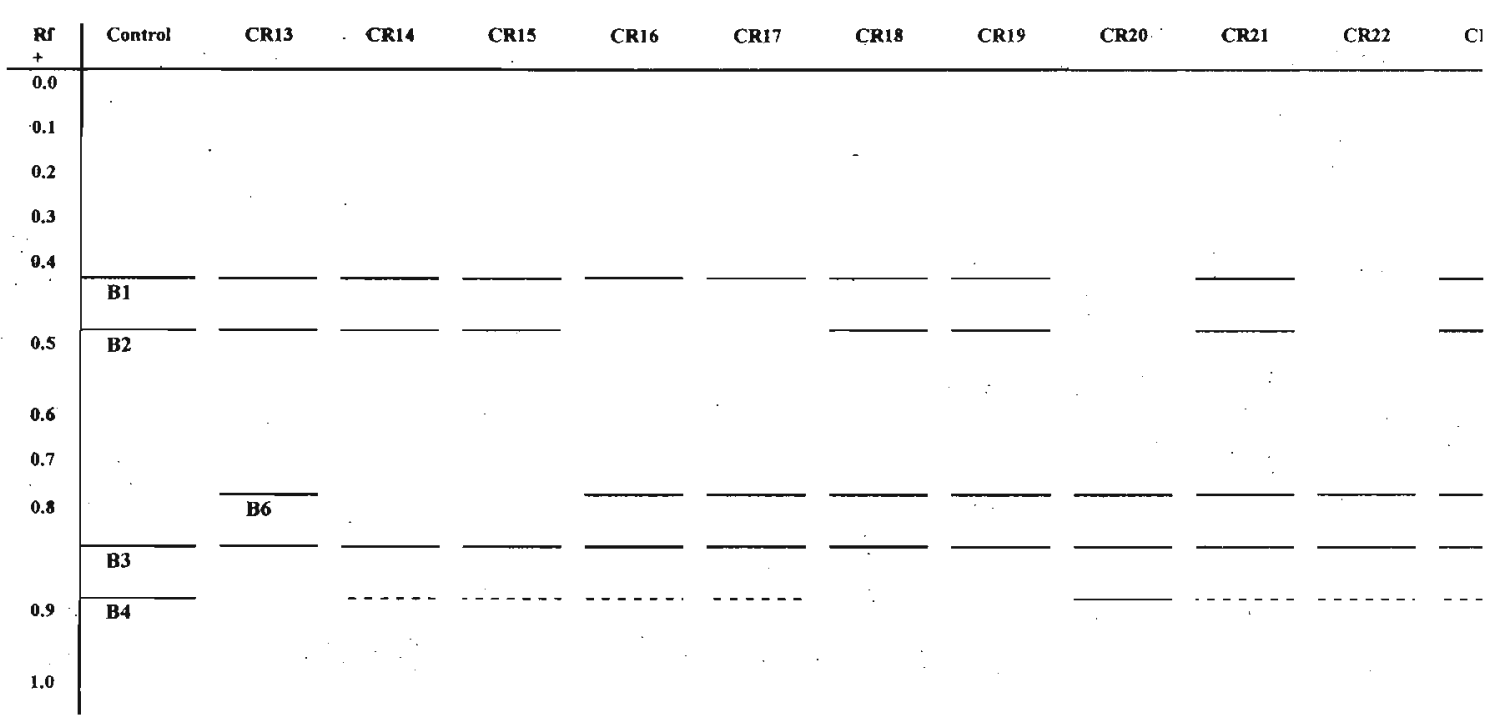

Figure 3 contd.: Zymogram of Peroxidase analysis for stem calli - derived innala plants

Control : Shoot-tip cultured plants

CR13 - CR23 : Stem calli - derived plants

lead to the production of an innala variety with large - sized tubers.

\section{Acknowledgment}

Author acknowledges Senior Deputy Director, Plant Genetic Resources Center, Peradeniya for providing facilities to carry out this study; Mr. C Manawaprema, PGRC for isozyme analyses; Mr. $J$ Chandrasiri, Horticultural Crop Research \& Development Institute, Peradeniya for statistical analysis and Audio Visual Centre, Department of Agriculture for photography.

\section{APPENDICES}

\section{Appendix I}

Extraction buffer

Tris - hydrochloric acid

$1.2 \%(\mathrm{w} / \mathrm{v})$

Glycerol

Polyvinyl pyrrolidon (PVP)

$20 \%(\mathrm{w} / \mathrm{v})$ $4 \%(\mathrm{w} / \mathrm{v})$

Dithiothreitol

$0.15 \%(\mathrm{w} / \mathrm{v})$

$\mathrm{MgCl}_{2}$

Distilled water

$0.4 \%(\mathrm{w} / \mathrm{v})$ $\mathrm{pH} 7.5$

Electrode buffer

Tris - hydroxymethyl amino methane

Glycine

Distilled water

\section{Appendix II}

Stain for peroxidase

3-amino 9-methyl carbosole

$20 \mathrm{mg}$

$\mathrm{N}, \mathrm{N}$-dimethyl formide

$3.0 \mathrm{ml}$

Acetate buffer (1M: pH 4.65)

$5.0 \mathrm{ml}$

$\mathrm{CaCl}_{2}$ solution $(0.1 \mathrm{M})$

$1.0 \mathrm{ml}$

Distilled water

$40 \mathrm{ml}$

$\mathrm{H}_{2} \mathrm{O}_{2}$ solution $(7 \% \mathrm{v} / \mathrm{v})$ 


\section{References}

1. Tindall H. D. (1993). Vegetables in the Tropics. The Macmillan Press Ltd, UK, pp. 533.

2. Gunasena H. P. M. (1997). Kshetra bhoga nishpadanaya. M D Gunasena \& Co. Ltd., Sri Lanka, pp. 624.

3. Shepard J. F., Bidney D. \& Shahin E. (1980). Science 208:17.

4. Nino T., Hettiarachchi A., Takahashi J. \& Samarajeewa P. K. (2000). Cryo Letters. Nov. Dec. 21(6): $349-356$.

5. Murashige T. \& Skoog F. (1962). A revised medium for rapid growth and bioassays for tobacco tissue cultures. Physiologia Plantarum 15:473-497.

6. Nitsch J. P. \& Nitsch C. (1969). Haploid plants from pollen grains. Science 163:85-87.

7. Rajapakse D. P., Mendis M. H. \& Ganashan P. (1995). Tissue culture of innala [Solenostemon rotundifolius (Poir.) J. K. Morton]: high frequency plant regeneration from leaf explants. Ceylon Journal of Science (Bio Sci.) 24(1): 1-5.
8. Uchimiya H. \& Murashige T. (1974). Evaluation of parameters in the isolation of viable protoplasts from cultured tobacco cells. Plant Physiology 54: 936 - 944.

9. D'Amato F. (1989). Polyploidy in cell differentiation. Carylogia 42:183-211.

10. Karp A. (1994). Origins, causes and uses of variation in plant tissue culture. In : Plant Cell and Tissue Culture. (Eds. I. K. Vasil \& T. A.Thrope). pp. 139-151. Kluwer Academic Publishers, The Netherlands.

11. Wochok Z. S. \& Burleson B. (1974). Isoperoxidase activity and induction in cultured tissues of wild carrot: a comparision of proembryos and embryos. Physiologia Plantarum 31: 73-75.

12. Wolter K. E. \& Gordon J. C. (1975). Peroxidase as indicators of growth and differentiation in Aspen callus cultures. Physiologia Plantarum 33:219-223. 